\title{
Sukupolvenvaihdoksen onnistuminen ja vaikutukset perhesuhteisiin
}

\author{
Kuosmanen, Janne ${ }^{1}$; Oinonen, Mari ${ }^{1}$; Paldanius, Kalevi ${ }^{1}$; Kainulainen, Petri ${ }^{1}$; Suhonen, Pirjo ${ }^{1}$; Lintunen,
} Sirpa $^{2}$ :

1) Savonia-ammattikorkeakoulu, PL 72, 74101 Iisalmi, etunimi.sukunimi@ savonia.fi

2) MTK, Pohjois-Savo Kuopio, etunimi.sukunimi@ mtk.fi

\section{TIIVISTELMÄ}

Pohjois-Savossa maatiloilla tehdään 120-130 sukupolvenvaihdosta vuosittain. Vuonna 2012 viljelijöiden keski-ikä oli 51,7 vuotta, ja yli 55-vuotiaiden viljelijöiden määrä oli liki $40 \%$. Tämä tarkoittaa, että lähivuosina yhä useammat viljelijät saavuttavat eläkeiän, jolloin myös sukupolvenvaihdosten määrä tulee nousemaan. Tutkimuksessa on kartoitettu, kuinka sukupolvenvaihdokset ovat kohdetiloilla sujuneet, ja miten sukupolvenvaihdos vaikuttanut perhesuhteisiin.

Sukupolvenvaihdoksella tarkoitetaan yrityksen omistuksen siirtymistä henkilöltä toiselle.

Sukupolvenvaihdos voidaan toteuttaa vaiheittaisena hyvin suunniteltuna prosessina, mutta se saattaa tapahtua myös yllättäen, esimerkiksi yrittäjän kuoleman seurauksena. Sukupolvenvaihdosta ohjaavat monet lait ja siihen liittyy paljon erilaisia henkilö- ja rahoituskysymyksiä sekä tunteita, asenteita ja sosiaalisia paineita. Sukupolvenvaihdos voidaan nähdä muutosprosessina, jolla pyritään varmistamaan yrityksen kannattavuus, vakavaraisuus sekä jatkuvuus. Sukupolvenvaihdoksen tekemiseen tulee varata aikaa, jotta luopuja sekä jatkaja ovat valmiita siirtymään uusiin rooleihinsa. Jatkajalla tarkoitetaan henkilöä, joka ryhtyy jatkamaan yritystoimintaa josta luopuja siirtää päätäntävallan ja vastuun toiselle henkilölle, jatkajalle. Jatkaja on henkilö, jonka nimiin yrityksen omistus siirtyy, ja luopujan voidaan sanoa siirtyvän sivustakatsojan rooliin.

Ihmissuhteet ovat merkittävässä osassa etenkin perheyrityksissä. Perheyritykseen kuuluu perhe, liiketoiminta sekä omistajuus, ja on mahdollista että yritystoiminta nivoutuu muun elämän kanssa tiiviisti yhteen, ja näitä kahta voi olla joskus vaikea erotella toisistaan. Perheyrityksessä ihmissuhteilla on suuri merkitys ja vaikutus yritykseen, mutta yritys vaikuttaa myös yrityksen sisäisiin ihmissuhteisiin. Perheyrityksissä tavoitteellisempaa on turvata yrityksen jatkuvuus kuin lyhyellä tähtäimellä saatavat voitot. Erityisesti sukutiloilla pidetään tärkeänä tilan jatkumista suku-polvien ajan.

Kysely lähetettiin Pohjois-Savossa vuonna 2010-2012 sukupolvenvaihdoksen tehneille tiloille, vastausprosentti oli 24,5\% ( $=167)$. Vastaajajoukko edustaa melko hyvin Pohjois-Savon nuorten viljelijöiden joukkoa, mutta vähäisen vastausmäärän takia tuloksia ei kannata yleistää liikaa. Vastaajiksi ovat saattaneet valikoitua vain ne tilat, joilla on mennyt hyvin.

Tuloksista käy ilmi, että kyselyyn vastanneiden sukupolvenvaihdokset ovat onnistuneet pääasiassa hyvin. Ongelmia ei ole ollut muutamia yksittäisiä tapauksia lukuun ottamatta. Asiantuntijoilta oli saatu enimmäkseen riittävästi apua sukupolvenvaihdokseen ja tämä apu koettiin tarpeelliseksi. Vastausten mukaan sukupolvenvaihdoksen asiantuntijapalveluissa voitaisiin enemmän huomioida ihmissuhteet ja herättää keskustelua sukupolvenvaihdoksen tekijöiden välillä niistä. Sovittavista asioista oli päästy pääsääntöisesti hyvin yhteisymmärrykseen, eivätkä perhesuhteet olleet muuttuneet valtaosalla vastaajista. Tehtyjen ratkaisujen ja sukupolvenvaihdoksen onnistumisen välillä ei vaikuta olevan tiettyä kaavaa.

Asiasanat: Sukupolvenvaihdos, perhe, ihmissuhteet 


\section{Johdanto}

Sukupolvien väliset suhteet ovat muuttuja, joka vaikuttaa kaikkeen siihen mitä maatilalla tapahtuu. Erityisesti tämä korostuu silloin kun tilan hallinta ja johtaminen siirtyvät uudelle sukupolvelle. Tilan omistajuuden siirtyminen ei ole vain kahden sukupolven kauppa, vaan usein useamman sukupolven yli ulottuva "lähetin" tehtävä. Idea sukutilasta ja jatkuvuudesta symboloivat talonpoikaista elämäntapaa ja sen arvoja. Tilaa ei mielellään luovuteta ulkopuoliselle eikä sukupolvien työtä haluta hukata perinteen katkeamiseen. Jatkajan on liityttävä sukupolvien ketjuun ja tässä mielessä hän on sukupolvien yli ulottuvan tehtävän lähettiläs.

Artikkelissa sukupolven käsite ymmärretään genealogisena, suvun sisäiseen merkitykseen ja sukulaisuusjärjestelmään viittaavana terminä. Tällöin se avaa näkökulmia perhesosiologiaan, elämänkulkuun, ikääntymiseen ja vanhempien ja lasten välisiin suhteisiin. (Purhonen 2007) Maataloustuotanto on Katilan (2000) mukaan erityistä sen organisatorisen perusyksikön eli sukupolvelta toiselle siirtyvän perheviljelmän vuoksi eli tila on tuotantoyksikkö ja kulutusyksikkö, työyhteisö että perheyhteisö, työpaikka että koti. Paikka jossa julkinen ja yksityinen, vapaa-aika ja työaika eivät erotu selkeästi toisistaan.

Katila (2000) on kuvannut sukupolvenvaihdostilanteita jatkuvuuden arvon kohtalonhetkiksi, hetkiksi joissa jatkaja sitoutuu jatkuvuuden arvoon. Tämän tutkimuksen taustalla on se erilaisissa keskusteluissa esiintyvä oletus, että sukupolvenvaihdos maatiloilla olisi ihmissuhteita koetteleva prosessi. Näin siksi, että sukupolvenvaihdos sisältää merkittävän siirtymän niin luopujien kuin jatkajien elämänkulussa. Keski-ikäisten vanhempien ja heidän lastensa väliset suhteet ovat tavallisesti positiivisia ja rakastavia. (Pulkkinen 2000, 276). Pulkkisen havainto on 15 vuotta vanha, mutta julkisessa keskustelussa ei ole ilmennyt mitään sellaista, joka antaisi aihetta olettaa tilanteen väestötasolla radikaalisti muuttuneen,

\section{Aineisto ja menetelmät}

Tutkimuksen kohderyhmänä oli Pohjois-Savossa vuosina 2010-2012 sukupolvenvaihdoksen tehneet maatilat. Aineisto kerättiin käyttämällä sähköistä webropol-kyselyä. Vastausohjeet ja linkki kyselylomakkeeseen toimitettiin vastaajille sähköpostitse. Kysely lähetettiin 167:ään sähköpostiosoitteeseen. Vastauksia tuli 41 kappaletta, jolloin vastausprosentiksi muodostuu 24.5. Vastaajien ikä tilakaupan tekohetkellä vaihteli alle 20-vuotiaasta 35 vuoteen, 20-25 -vuotiaat muodostivat suurimman ryhmän (32\%). Aineistosta analysoitiin frekvenssi- ja prosenttijakaumin. Muuttujien riippuvuussuhteiden analyysi ei pienen N:n takia ollut tilastollisesti mielekästä.

\section{Tulokset ja tulosten tarkastelu}

Kyselyyn vastanneiden osalta jatkuvuuden arvo näyttää olevan vielä voimissaan. Kaikilla kyselyyn vastanneilla oli sukutila. Kahdella kolmasosalla tila oli ollut suvun hallussa neljän sukupolven ajan tai kauemmin. Kuusi sukupolvea tai sitä kauemmin saman tilan omistaneita oli 28 prosentilla. Yksikään vastanneista ei ollut ostanut tilaa ulkopuoliselta. (ks. kuvio 1) 


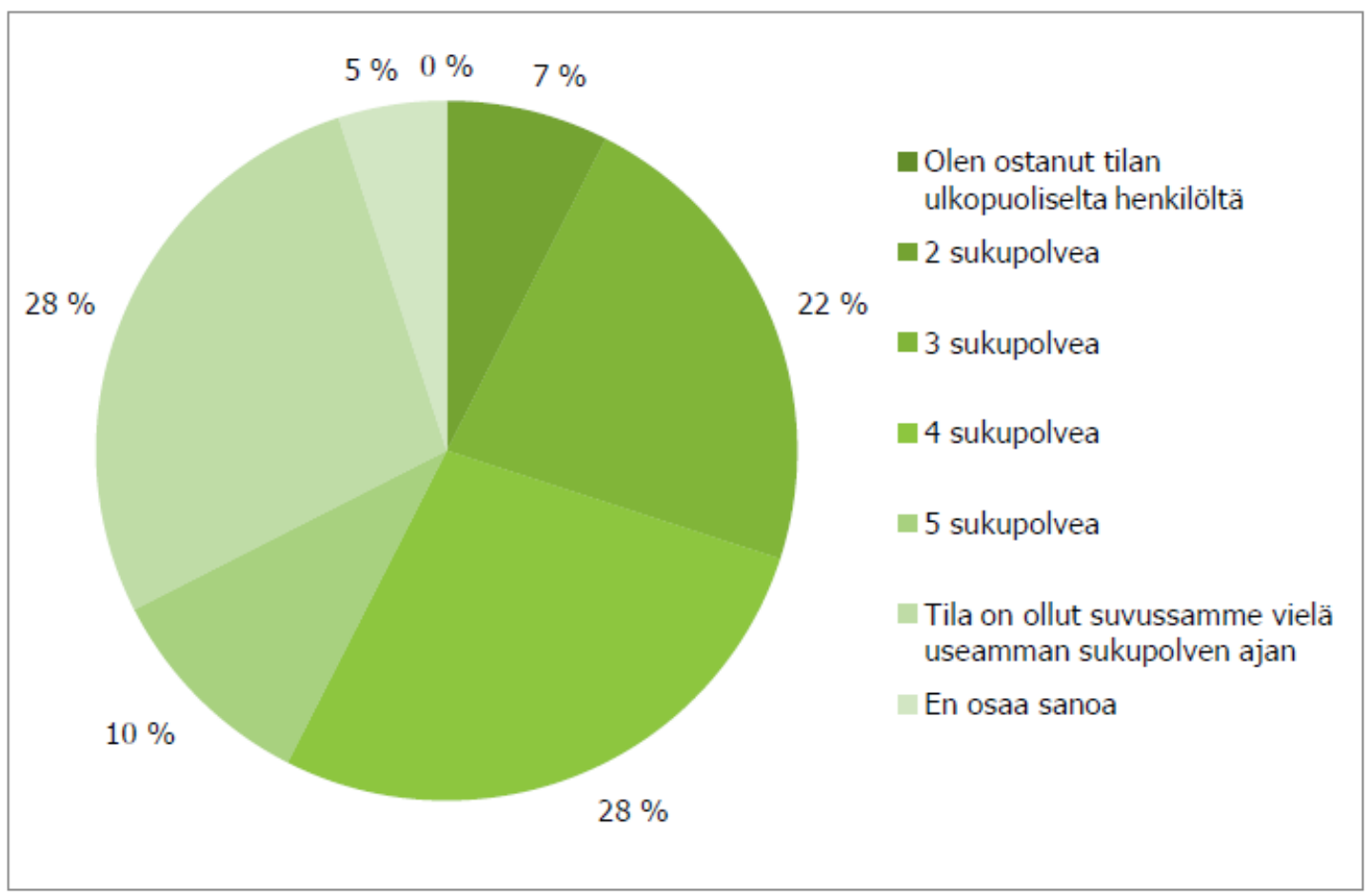

Kuvio 1. Kuinka monta sukupolvea tila on ollut saman suvun omistuksessa $(n=41)$

Jatkuvuuden arvoon sitoutuminen näyttää aineiston valossa tapahtuvan pääasiassa jatkajan omasta tahdosta. Sisaruksia ei joko ollut tai nämä eivät olleet kiinnostuneet jatkamisesta. Kahdessa tapauksessa useampi lapsista oli ollut kiinnostunut jatkamaan. Tällöin ratkaisuna oli ollut maatalousyhtymän perustaminen. Kahdessa vastaavassa tapauksessa luopuja oli valinnut jatkajan. Olennaista on, että jatkajan kiinnostus painoi valinnoissa enemmän kuin luopujan toiveet ts. vastausten mukaan ketään ei ollut painostettu jatkamaan tilaa.

Sukupolvenvaihdostilanteessa tiloille on tarjolla neuvontaorganisaatioiden asiantuntija-apua. Vastaajien kokemusta avun riittävyydestä tiedusteltiin pyytämällä heitä arvioimaan palveluja koskevia väitteitä likert-tyyppisellä asteikolla (täysin samaa mieltä, jonkin verran samaa mieltä, jonkin verran eri mieltä ja täysin eri mieltä.) Vastaajat voivat valita myös vaihtoehdon "en halunnut käyttää tai tarvinnut palvelua" tai "palvelua ei ollut tarjolla vaikka olisi sitä tarvinnut." Kysymys kattoi monia sukupolvenvaihdokseen liittyviä asioita alkaen vaihdosprosessin käynnistämisestä kauppahintaan lakiasioihin ja verotukseen.

Perhesuhteiden hoitamiseen saatu apu oli mukana yhtenä osiona. Tässä esitetään vain tähän saadut vastaukset. Perhesuhteiden hoitamiseen annetun avun koki täysin riittäväksi $15 \%$ vastaajista. Väitteen kanssa jonkin verran samaa mieltä olevia oli $20 \%$ vastaajista. Palveluihin tyytyväisiä oli siis kolmannes vastaajista. Mutta lähes kolmannes $(32 \%)$ oli jonkin verran tai täysin eri mieltä. Saman verran oli niitä, jotka eivät olleet tarvinneet tai eivät olleet halunneet käyttää palvelua. Toisaalta $68 \%$ vastaajista piti palvelua erittäin tai jokseenkin tarpeellisena. "Ei kovin tarpeellisena" palvelua piti neljännes vastaajista.

Sukupolvenvaihdoksen eri vaiheiden (suunnittelu, toteutus ja tilakaupan jälkeinen aika) vastaajat olivat kokeneet sujuneen pääosin myönteisesti. Viidesosalla kaikki vaiheet olivat 
menneet erittäin hyvin ja noin kolmasosalla hyvin. Kuviossa kaksi on koottuna vastaajien arviot sukupolvenvaihdoksen eri osa-alueiden onnistumisesta.

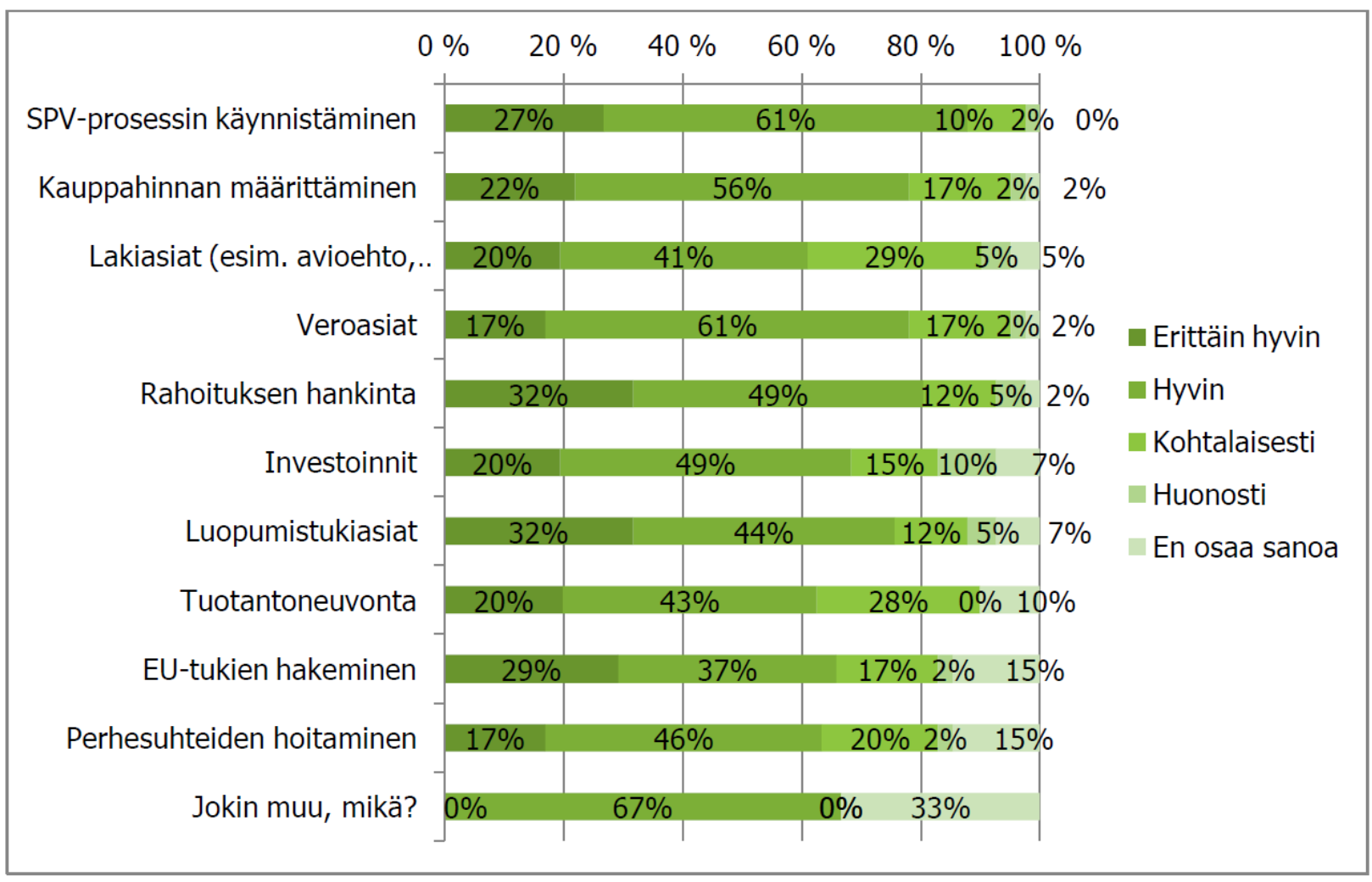

Kuvio 2. Sukupolvenvaihdoksen eri osa-alueiden onnistuminen

Perhesuhteiden hoitaminen on sujunut erittäin hyvin tai hyvin lähes $2 / 3$ vastaajista. Viidennes arvioi perhesuhteiden hoituneen kohtalaisesti. Yksi vastaaja koki perhesuhteiden hoitamisen sujuneen huonosti. 15 prosenttia ei osannut sanoa miten perhesuhteet ovat hoituneet.

Kuva tilanteesta muuttuu hieman rosoisemmaksi vastauksissa kysymykseen millaisia vaikeuksia sukupolvenvaihdoksen jälkeen oli kohdattu. Asiat ovat menneet arvion mukaan suurella osalla tiloista hyvin. Mutta kuitenkin viidenneksellä oli ollut ongelmia sisarusten kanssa, reilulla kolmanneksella puolison kanssa ja viidenneksellä luopujien kanssa. Näiden ongelmien oli koettu haittaavan suuresti tilan toimintaa. Joissakin tapauksissa tilan selviäminen oli ollut vaakalaudalla näiden ihmissuhdeongelmien vuoksi.

Luopujien osallistuminen tai osallistumattomuus tilan töihin on potentiaalinen ongelmien lähde. Tilannetta helpottaa, mikäli osallistumiskäytännöistä tehdään selkeä sopimus. Vastaajien joukossa luopujan tai luopujien osallistumisesta tilan töihin oli suurimmassa osassa tapauksia sovittu suullisesti $(62 \%)$ ja vain muutamassa tapauksessa kirjallisesti (5\%). Kolmasosa vastaajista oli jättänyt sopimuksen täysin tekemättä. Joihinkin töihin osallistumisessa näkyy työnjaon jonkin asteinen sukupuolittuneisuus. Karjanhoitotöihin osallistuivat sekä vanha emäntä että vanha isäntä suhteellisen tasaisella osuudella. Rakennustöihin ja koneiden huoltotöihin ei osallistunut yksikään vanha emäntä. Vanhoista isännistä kaksi osallistui kotitaloustöihin ja seitsemän lastenhoitoon, mutta nämä työt olivat selkeästi useammin vanhan emännän vastuulla. 
Metsän hoito- ja peltoviljelytöihin osallistuminen lankesi vanhoille isännille, mutta muutama vanha (neljä/kaksi) emäntäkin otti osaa näihin töihin.

Luopujien apu koettiin hyödylliseksi (yli $70 \%$ ) ja saadusta avusta oltiin iloisia. Neljä vastaajaa oli sitä mieltä, että luopujasta on hyötyä, mutta hänen mukana olonsa töissä koettiin kuitenkin epämiellyttäväksi.

Sukupolvenvaihdoksissa tilan omistajuus ja johtaminen siirtyvät jatkajalle. Tilan kehittämiseen ja esimerkiksi tuotantosuunnan vaihtamiseen liittyvät ratkaisut ovat strategisia päätöksiä. Sukupolvenvaihdos voi tarjota tilaisuuden vaihtaa tilana tuotantosuuntaa. Vastaajien joukossa tilan tuotantosuunta oli säilynyt suurimmalla osalla (78 \%) samana eli maidontuotantona.

Uudella sukupolvella voi olla tilan kehittämisestä omia ideoita, jotka eivät sovi luopujien käsityksiin maatilan toiminnasta. Vastausten perusteella sekä ennen sukupolvenvaihdosta että sen jälkeen tilan kehittämisessä on kuunneltu jatkajan toiveita (taulukko 1) ja muutamassa tapauksessa luopujan toiveet ovat tulleet kuulluiksi. Joissakin tapauksissa jatkaja on tehnyt päätökset ilman luopujan lupaa ja joissakin luopujan tahto on sanellut tilan kehittämisen suunnan. Yleisarvio tilanteesta on, että kehittämisestä on päätetty yhteisymmärryksessä

Taulukko 1. Tilan kehittämisestä päättäminen ennen ja jälkeen sukupolvenvaihdoksen (spv)

\begin{tabular}{|l|l|l|l|}
\hline & $\begin{array}{l}\text { Ennen } \\
\text { spv:ta } \\
(\mathrm{n}=40)\end{array}$ & $\begin{array}{l}\text { Spv:n } \\
\text { jälkeen } \\
(\mathrm{n}=39)\end{array}$ & $\begin{array}{l}\text { Vastauksia } \\
\mathrm{kpl}\end{array}$ \\
\hline $\begin{array}{l}\text { Tilaa on kehitetty jatkajan haluamaan suuntaan luopujan } \\
\text { suostumuksella }\end{array}$ & $54 \%$ & $46 \%$ & 28 \\
\hline $\begin{array}{l}\text { Tilaa on kehitetty jatkajan haluamaan suuntaan vastoin luopujan } \\
\text { suostumusta }\end{array}$ & $40 \%$ & $60 \%$ & 5 \\
\hline $\begin{array}{l}\text { Tilaa on kehitetty luopujan haluamaan suuntaan jatkajan } \\
\text { suostumuksella }\end{array}$ & $50 \%$ & $50 \%$ & 6 \\
\hline $\begin{array}{l}\text { Tilaa on kehitetty luopujan haluamaan suuntaan vastoin jatkajan } \\
\text { suostumusta }\end{array}$ & $67 \%$ & $33 \%$ & 3 \\
\hline Tilan kehittämisestä on päätetty yhteisymmärryksessä & $49 \%$ & $51 \%$ & 37 \\
\hline
\end{tabular}

Vastaajilta tiedusteltiin myös heidän arviotaan sukupolvenvaihdoksen vaikutuksista ihmissuhteisiin. Pääosin välien sisaruksiin, luopujiin ja puolisoon oli koettu pysyneen samanlaisina tai lähentyneen. Välien etääntymistä oli kokenut muutama. Vain yhdessä tapauksessa jatkaja ei ollut lainkaan tekemisissä luopujien kanssa.

\section{Johtopäätökset}

Kyselyn alhainen vastausprosentti rajoittaa tilastollisten päätelmien ja yleistysten tekoa. Tuloksia voi pitää suuntaa antavina. Mahdollista on, että vastaajiksi ovat valikoituneet ne, joilla sukupolvenvaihdos on mennyt eri osiltaan hyvin ja nykytilanteeseen ollaan tyytyväisiä. Aineiston valossa sukupolvenvaihdokseen liittyvät monet taloudelliset ja juridiset kysymykset on onnistuttu hoitamaan erittäin hyvin tai hyvin. Myös perhesuhteet ovat säilyneet ennallaan, joissakin tapauksissa jopa lähentymistä on tapahtunut. Kyselyaineisto ei kerro eikä kuvaa itse vaihdosprosessia ja siihen sisältyviä tilanteita ja positiivisten ratkaisujen syntyä, joista voisi omaksua hyviä toimintatapoja. Yhteistyö perheiden sisällä ja sukupolvien välillä sekä rahoittajien, asiantuntijoiden ja viranomaisten kanssa ovat niitä elementtejä, joilla onnistunut SPV tehdään. 
Kirjallisuus

Katila, S. 2000. Moraalijärjestyksen rajaama tila: maanviljelijä-yrittäjäperheiden selviytymisstrategiat. Helsinki School of Economics and Business Administration. Acta universitatis oeconomicae Helsingiwnsis A- 174.

Kuosmanen, J. \& Oinonen, M. 2014. Sukupolvenvaihdoksen onnistuminen ja vaikutukset perhesuhteisiin. Opinnäytetyö. Savonia-ammattikorkeakoulu. Maaseutuelinkeinojen koulutusohjelma.

Pulkkinen, L 2000. Developmental Psychology II: Adulthood and Aging. Teoksessa K. Pawlik \& Mark R. Rosenzweig (toim.) The International Handbook of Psychology. (ss. 261 - 282). London: Sage.

Purhonen, S. 2007. Sukupolvien ongelma. Tutkielmia sukupolven käsitteestä, sukupolvitietoisuudesta ja suurista ikäluokista. Helsingin yliopiston sosiologian laitoksen tutkimuksia nro 251. 